\title{
Prospek dan Masalah Ketenagakerjaan di Sektor Industri Kecil
}

\author{
Oleh : Musa Asy'arle
}

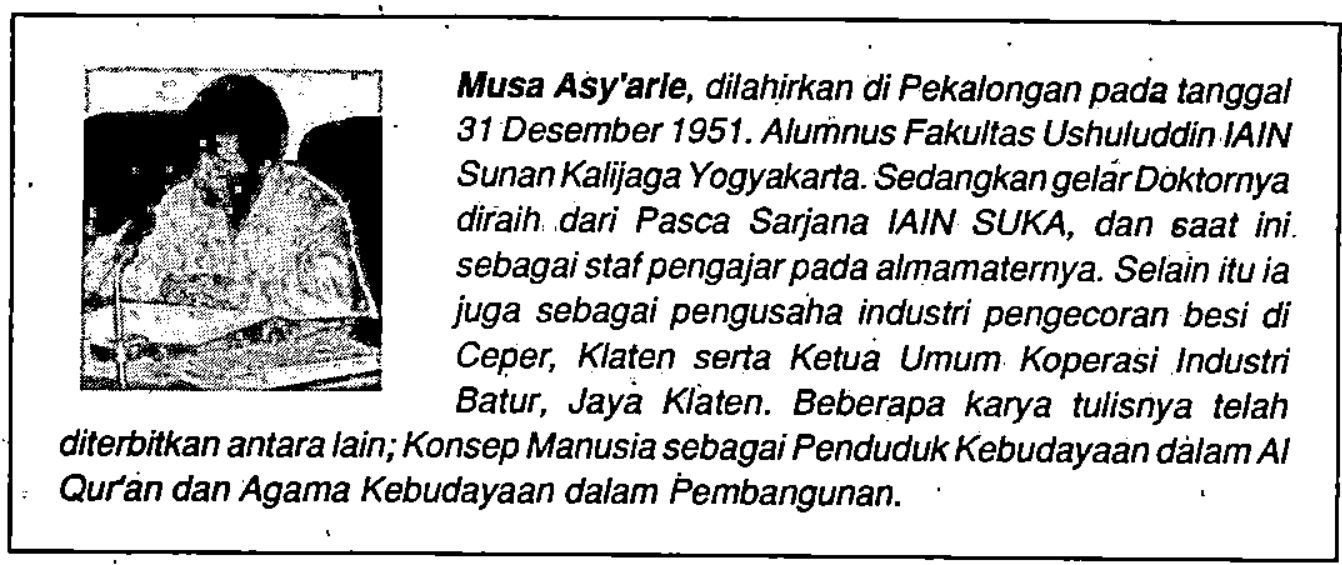

\section{Pendahuluan}

Presiden Suharto dalam laporan pertanggungjawabannya di depan sidang MPR tanggal 1 Maret 1993 menegaskan bahwa selama lebih dari dua dasawarsa terakhir, sektor industri telah tumbuh lebih cepat dari sektor-sektor lain; yaitu dengan rata-rata lebih dari $12 \%$ per tahun. Dengan perkembangan yang pesatitu peranan sektor industri dalam produksi nasional telah meningkat dari 9,2\% dalam tahun 1969 menjadi $21,3 \%$ dalam tahun 1991 .

Penegasan tersebut tentu saja mengembirakan, karena diharapkan terjadi keseimbangan antara sektor industri dan sektor pertanian. Akan tetapi jika kita lihat pada realitas sektor industri kita, maka nampak adanya gejala yang menunjukkan bahwa struktur industri kita pada umumnya masih lemah, baik dilihat pada kemampuan menyeraptenaga kerja maupun kemampuan daya saingnya di pasaran intemasional. The Kian Wie (Industrialisasi Indonesia -
Analissis dan Catatan Kritis) menyatakan bahwa pertumbuhan industri besar dan sedang yang cukup pesat dalam tahun-tahun mendatang tidak akan dapat banyak -menyerap tenaga kerja baru yang tiap tahun bertambah kurang lebih 1.5 juta orang, sementara lapangan kerja baru yang diciptakan oleh industri-industrikita selama kurun waktu 1975-1982 hanya tersedia untuk kuranglebih 45.000 orang. Jadi setiap tahun industri besar dan sedang hanya mampu menyerap sampai $5 \%$ dari seluruh pertambahan pada angkatan kerja.

Dalam soal penyerapan tenaga kerja di bidang industri, data statistik 1974-1975 menunjukkan bahwa industri rumah tangga memberikan peluang lebih besar, mencapai $80 \%$ meskipun nilai tambahnya rendah (sekitar 13\%). Sebaliknya industri besar hanya menyerap tenaga kerja $13 \%$ dengan nilai tambah $80 \%$, sementara itu industri kecil dapat meyerap tenaga kerja $7 \%$ dengan nilai tambah $7 \%$. 
Terlepas dari soal kemampuan: menyerap tenaga kerja, secara keseluruhan dapatlah dikatakan bahwa struktur industri : kita juga masih belum kuat, terutama dalam yang dimilikinya.

\section{menhadapi persaingan global pasaran} internasional. Rizal Ramli antara lain eiklimit. usaha juga menunjukkan menunjukkan bahwa proteksi terhadap industri otomotif Indonesia terlihat pada tingkat proteksi nominal mencapai $80 \%$, , tetapi jika dimasukkan efek dari semua tarif : komponen dan pembatasan inpor mobil, maka tingkat proteksi efektif luas biasa tingginya, bisa sampai $60 \%$. Dengan tingkat proteksi setinggi itu tidak aneh jika banyak merek (mobil) bisa tetap survive, walau tingkat produksi masih hanya beberapa ribu unit saja (Kompas 1 Maret 1993, hal. 2).

Sementara itu kita pun dapat melihat betapa banyak industri-industri kita yang jatuh oleh karena tidak mampu bersaing di pasar bebas, seperti yang dialami oleh industri pertenunan kita. Hal yang sama sekarang juga melanda industri karoseri dan industri kecil pandai besi.+"Daftar tunggu" kejatuhan itu mungkin akan masih banyak lagi dan merambat ke : berbagai bentuk industri kecil kita laiṇ̣ya.'

\section{Kelemahan Internal}

Kejatuhan industri kecil itu antara lain disebabkan oleh adanya kelemahankelemahan internal, yaitu: pertama adalah lemahnya permodalan, konon fasilitas kredit yang disalurkan kepada industri kecil kita hanya $5 \%$ saja dari dana kredit yang disalurkan olehperbankan nasional. Kedua adalah rendahnya tingkat penguasaan teknologi, sehingga memberikan nilai tambah yang rendah. Dengan nilai tambah yang rendah maka keuntungan yang diperolehnya menjadi kian kecil yang pada. gilirannya membuat mereka tidak mampu mengikuti perkembangan teknologi. Ketiga adalah sumberdaya manusianya, lemahnya .jiwa kewiraswastaan, baik pada tingkat pengusahanya maupun tingkat karyawan Di samping kelemahan internal ini, kecenderungan yang tidakk sehat, bahkan saling menghancurkan, baik disebabkan soleh dinamika ekstemal dengan munculnya perusahaan-perusahaan besar dengan teknologi tinggi, modal yang kủat serta manajemen yang efisien yang bersaing dengan industri-industri kecil sejenis, imaupun oleh dinamika internal, yaitu adanya persaingan yang tidak sehat antara industri-industri kecil yang berlomba saling menjatuhkan dengan harga pasar.

Akibat yang ditimbulkan oleh jatuhnya industri kecil dan industri rumah tangga adalah kian besarnya jumlah pengangguran. Menurut seorang peneliti dari Departemen Perindustrian selama kunun waktu Nopember 1968 sampai Maret 1973 perusahaan-perusahaan modern baru dalam industri pertenunan telah berhasil menciptakan produktivitas yang jauh lebih tinggi pada perusahaan-perusahaan modem dengan teknologi tinggi, membatasi ruang gerak perusahaan-perusahaan pertenunan tradisionil yang padat karya sehingga banyak perusahaan jenis ini terpaksa gulung tikar dengan akibat bahwa kurang lebih 391.000 pekerja di perusahaan ini diperkirakan telah kehilangan lapangan tenaga kerja.

Keterangan Dirjen Industri Kecil Departemen Perindustrian Ir. Trisura Suhardi dalam pertemuan dengan para pengusaha cor logam di Koperasi Batur Jaya 3 Maret 1993, menjelaskan bahwa kejatuhan industri kecil sekarang telah merambat ke industri karoseri dan pandai besi yang jumlahnya cukup besar. 
Kejatuhan itu lebih disebabkan oleh dampak globalisasi ekonomi, di mana industri kecil kita harus menghadapi persaingan ketat dengan produksi luar negeri yang lebih efisien.

Jatuhnya industri-industri kecil yang masih akan terus berlangsung, jika tidak segera dilakukan program pembinaan yang sistematis, maka akan menimbulkan masalah-masalah ketenagakerjaan yang berdampak pada ketidakstabilan sosial politik, yang pada saatnya ałkan mengancam kelangsungan pembangunan itu sendiri.

\section{Lokasi Industri Kecil}

Pada umumnya industri kecil kita berada di daerah pinggiran kota dan pedesaan. Di daerah-daerah ini, kultur industri yang sifatnya rašional pragmatik belum sepenuhnya berkembang. Oleh karena itu, keuntungan yang diperoleh biasanya tidak dipakai untuk memperkuat dan mendalami struktur industrinya, tetapi untuk keperluan lain yang tidak berkaitan dengan kegiatan ekonomi. Demikian juga halnya dalam memecahkan persoalanpersoalan yang muncul dalam kegiatan usahanya, biasanya jawaban yang diberikan tidakberkaitanlangsung dengan pemeçahan masalah yang terjadi di lapangan, tetapi melihatnya sebagai bagian dari nasib. Konsep takdir di bidang ekonomi yang masih berkembang kuat di kalangan masyarakat industri pedesaan kita, rasanya juga punya andilmemperlemah tumbuhnya budaya industri.

Pada tahap ini yang sesungguhnya terjadi adalah adanya konflik budaya, yaitu budaya industrial dengan budaya agraris. Kegiatan industri hanya akan berkembang maju jika didukung oleh budaya industriál, sebaliknya jika kegiatan industrial berlangsung dalam alam budaya agraris, maka kegiatan industrinya akanmengalami kesulitan untuk berkembang dan pada gilirannya akan memperlemah daya saingnya.

Kegiatan industri kita pada dasarnya belum didukung lahimya budaya industrial. Jika selama ini ' telah terjadi pergeseran kegiatan ekonomi nasional yang tidak lagi bergantung pada sektor pertanian, bahkan sektor industri telahberkembanglebih maju di lihat pada sumbangan sektor industri pada tingkat produksi nasional yang melebihi sëktor pertanian, maka dalam tahap budaya ternyata belum terjadi pergeseran, sehingga industri. kita masih bertumpu pada budaya agraris.

Di samping itu, kita-juga melihat gejala adanya kesenjangan antara budaya kerja industri besar dengan teknologi yang sudah tinggi, dengan budaya kerja industri kecil dengan peralatannya yang masih sederhana. Kesenjangan budaya kerja ini tercermin dari kualitas produksi, kualitas sumber daya manusia, serta tingkat kesejahteraan dan keselamatan yang diterima oleh tenaga kerja. Kesenjangan yang makin jauh, mengakibatkan sulitnya dijalin hubungan kerja antara inđustri besar dengan industri kecil, sehingga upaya pembinaan yang saling memperkokoh di antara keduanya menjadi makin sulit.

\section{Konsep Kerja}

Konflik budaya antara budaya 'industrial dan agraris ini mengakibatkan pula adanya konsepkerja bidang industrial yang tidak produktif. Kerja tidak lagi dipandang sebagai usaha mencapai tingkat produksi yang setinggi-tingginya, tetapi sebagai bagian untuk mengisi kegiatan hidup saja yang sifatnya rutin. Budaya kerja yang berkembang adalah budaya kerja yang selaras dan seimbang dengan tuntutan 
tradisional. Oleh karena itu, kegiatan kerja mesti dihentikan jika kegiatan-kegiatan yang sifatnya tradisional, seperti kegiatan sadranan dan semacamnya.

Para ahli ilmu sosial seringkali menyatakan bahwa kehidupan di desa sifatnya adalah paguyuban. Pernyataan ini adalah benar jika kita lihat pada kegiatan kemasyarakatan pada umumnya. Akan tetapi jika kita melihatnya pada kegiatan ekonomi pedesaan, terutamá pada masyarakat industri pedesaan, ternyata konsep paguyuban itu tidak tercermin lagi. Sebaliknya persaingan antar mereka berlangsung sangat ketat dan nyaris kejam, pembajakan karyawan tidak hanya terjadi pada tingkat perusahaan para konglomerat tetapi juga di tingkat industri kecil pedesaan, bahkan pembajakan relasi bisnis juga sering berlangsung dengan cara penurunan harga yang serendah-rendahnya.

Realitas persaingan yang tidak sehat ini sesungguhnya mempunyai andil yang cukupbesardalam proses jatuhnya industriindustri kecil kita, karena dengan bersaing menurunnkan harga hanya agar dapat menggaet relasi bisnis tetangganya, maka tingkatkeuntungan yang diperolehnya terus meluncur ke titik terendah, dan kemerosotan keuntungan ini mengakibatkan mereka tidakmampu melakukan peningkatan teknologi produksi yang berkembang makin pesat dan makin mahal harganya. Penurunan harga massal ini pada hakekatnya adalah penghancuran massal pada kehidupan industri pedesaan kita.

\section{Pendidikan}

Membicarakan sumberdayamanusia pada dasarnya tidak dapat dilepaskan dengan pendidikan. Pada umumnya pendidikan teknik kita yang diharapkan dapat menyediakan tenaga terampil bagi industri, masih belum sépenuhnya berorientasi pada tuntutan dan realitas dunia usaha yang akan menjadi tempat mereka bekerja, baik banyaknya muatan mata pelajaran yang tak terkait dengan dunia kerja secara kongkrit, maupun kultur kerja yang tak ditanamkan secara ketat sejak awal. Bahkan orientasi yang sifatnya feodalistik masih cukup tinggi, sehingga dunia usaha kita selalu merasa kekurangan tenaga teknik seperti yang diharapkan, padahal jumlah pengangguran makin banyak. Kultur kerja keras dan produktif belum tampak pada latihan kerja yang diselenggarakan dunia pendidikan kita, bahkan seringkali latihan kerja dipandang sekedarmemenuhi persayaratan lulus ujian.

Kebanggaan sebagai tukang harus ditanamkan sejak dini dalam kultur kerja yang produktif, sehingga puncak kebahagiaan seorang tukang akan tercapai, manakala ia menyaksikan hasil karyanya unggul secara teknik. Jika industrikita sudah bertumpu pada filosofi tukang ini, maka industri kita akan mendapatkan kekuatan sumber daya manusia yang dapat mendukung kemajuan dunia usaha.

Kultur kerja industrial yang memerlukan kerja keras ketekunan dan ketelitian yang tinggi agardapatmelahirkan produksi unggul yang mampu bersaing di pasaran, menjadi sulit tercapai, tanpa didukung sumber daya tukang, sehingga industri kecil kita hanya bisa menghasilkan produksi yang asal-asalan saja, kualitas tekniknya rendah serta waktu penyerahan yang seringkali tidak tepat.

Pada sisi yang lain, kita juga menyaksikan bahwa industri kecil kita belum sepenuhnya dapat memberikan imbalan kerja yang layak, yang memungkinkan para pekerja memperoleh motivasi baru untuk mencapai target 
produksi yang optimal. Sementara itu, karena struktur industri kecil sangat lemah, dengan tingkat keuntungan yang rendah, mengakibatkan para pengusaha tidak mampu memberikan imbalan yang layak, karena faktor upah dalam industri yang nilai tambähnya rendah merupakan faktor yáng utama yaing sangat berpengaruh pada harga jual produksi.

\section{Penutup}

Yang diperlukan sekarang adalah penataan dan pemetaan kegiatan di setiap jenjang industri dalam perekonomian nasional, dengan harapan agarindustrikecil tidak dibiarkan bersaing dengan industri besar dalam jenis produksi yang sama. Jangan sampai yang besằ menelan yang kécil. Oleh karena itu, program pembinaan industri kecil melalui bapak angkat, seharusnya diarahkan pada upaya memperkuat struktur industri kecil, dengan căra melibatkan industri kecil sebagai bagian industri besar.

Selanjutnya diperlukan adanya perubahan kultural padamasyarakat industri kita, dari kultur agraris ke kultur industrial, karena tanpa adanya basis kultur yang mendukung, rasanya sulit industri kita tumbuh kuat untuk bersaing dengan industri-industri bangss lain.

Perubahan kultural itu juga diharapkan mampu mengubah pandangan bahwa pemilikan kolektif lebih mulia daripada pemilikan individual. Pandangan ini penting karena tantangan industri dari hari ke hari makin berat, dimana untuk mengatasinya harus melibatkan banyak pihak. 